\title{
PRZYDATNOŚĆ ARKUSZA ROZLICZENIOWEGO KOSZTÓW DO ZARZĄDZANIA KOSZTAMI SPÓŁDZIELNI MLECZARSKIEJ
}

\author{
Marzena Ganc \\ Katedra Finansów \\ Szkoła Główna Gospodarstwa Wiejskiego w Warszawie
}

\begin{abstract}
Abstrakt. Celem badań jest przedstawienie schematu rozliczania kosztów w spółdzielni mleczarskiej oraz określenie jego przydatności w pozyskiwaniu informacji o kosztach dla potrzeb podejmowania decyzji zarządczych. Analizy mają charakter studium przypadku. Wybrano w sposób celowy spółdzielnię mleczarską określoną jako obiekt typowy przy wykorzystaniu metody odległości euklidesowej i miejskiej. W warunkach, w jakich gospodarują współczesne podmioty gospodarcze, potrzebne są wiarygodne informacje o kosztach. Dostarczanie tych informacji jest głównym zadaniem rachunku kosztów, który jest jedną z najważniejszych części składowych rachunkowości, mającą za zadanie grupowanie kosztów oraz ustalanie szeregu zależności między procesami produkcyjnymi, a wysokością kosztów. Prawidłowo sporządzony arkusz rozliczeniowy kosztów powinien uwzględniać zmiany zachodzące zarówno w technologii produkcji, jak i w otoczeniu rynkowym spółdzielni mleczarskiej, ponieważ czynniki te uzasadniają zapotrzebowanie na informację o kosztach.
\end{abstract}

Słowa kluczowe: arkusz rozliczeniowy kosztów, spółdzielnie mleczarskie, rachunek kosztów.

\section{WSTĘP}

Rachunek kosztów można określić jako proces ustalania kosztów prowadzenia działalności gospodarczej według określonego modelu [Morse, Davies, Hartgraves, 2013, s. 98]. Modelem rachunku kosztów jest nazywany zespół zasad i procedur, według których dokonuje się transformacji informacji o kosztach dotyczą- 
cych rozpatrywanych obiektów odniesienia kosztów w celu ich przystosowania do specyficznych potrzeb informacyjnych interesariuszy jednostki gospodarczej [Nowak 2010, s. 168].

Van Derbeck stwierdził, iż zarządzanie kosztami to zestaw technik i metod służących kontroli działalności oraz doskonaleniu procesów i produktów przedsiębiorstwa. W koncepcji tej zarządzający są ukierunkowani na optymalizację alokacji zasobów w najbardziej rentownych obszarach działalności gospodarczej oraz podwyższenie efektywności ich wykorzystania [Van Derbeck 2013, s. 58]. Definicja ta znajduje swoje zastosowanie również dla podmiotów spółdzielczych.

Ponoszenie przez jednostkę gospodarczą kosztów ma na celu stworzenie nowych wartości w postaci wytworzonych, szeroko rozumianych produktów. Akceptację na rynku uzyskuje jednak jedynie uzasadnione zużycie zasobów gospodarczych. W związku z tym nie każde zużycie tych elementów stanowić może koszt. Zużycie zasobów, którego wielkość przekracza rozmiary gospodarczo lub społecznie uzasadnione w danych warunkach techniczno-organizacyjnych bądź nie daje użytecznych efektów, nie jest kosztem, lecz stanowi stratę. Oszczędne zużycie zasobów wynika również z zasady gospodarności. Zasada ta winna być uwzględniana w każdej działalności i polegać na poszukiwaniu i wyborze najbardziej korzystnej relacji pomiędzy nakładami i efektami [Jaruga i in. 2010, s. 175]. Przestrzeganie zasady gospodarności oznacza racjonalne wykorzystywanie zaangażowanych zasobów i optymalizację kosztu jednostkowego, a więc zużycia na jednostkę produktu. Pojęcie kosztów oznacza wyrażone w pieniądzu celowe zużycie pracy żywej (wynagrodzenia za pracę z narzutem) i uprzedmiotowionej (amortyzacja majątku trwałego, zużycie materiałów, energii, usług obcych itp.) związane z celem realizowanej działalności. Prawa rynku są twarde, a utrzymują się na nim tylko ci wytwórcy, którzy produkują tanio, a dobrze i którzy znają na bieżąco sytuację na odcinku podaży i pobytu oraz orientują się w strukturze, poziomie i trendach w zakresie kosztów, zarówno we własnej firmie, jak w skali makroekonomicznej [Gabrusewicz, Kamela-Sowińska, Poetschke 1998, s. 223]. Dlatego tak istotne znaczenie ma prowadzenie rachunku kosztów, który jest ważnym elementem systemu rachunkowości. Rachunek kosztów jest to ogół czynności zmierzających do ustalenia wysokości nakładów pracy żywej i uprzedmiotowionej, poniesionych w przedsiębiorstwie w określonym czasie i z określonym przeznaczeniem. Rachunek kosztów dostarcza informacji o poniesionych kosztach oraz powinien odpowiedzieć na takie pytania jak: ile kosztuje wytworzenie określonych wyrobów i usług oraz ile można na tym zarobić. Bardzo ważne jest także śledzenie w tym kontekście trendów i wzajemnych korelacji przychodów, kosztów i wyniku netto w ujęciu dynamicznym, w ujęciu globalnym i analitycznym [Jaruga, Nowak, Szychta 1999, s. 35].

W licznej literaturze zagadnienia oraz w różnorodnych aktach prawnych nie funkcjonuje jednoznaczna definicja kosztu. Niemniej jednak można określić 
koszt jako wyrażone w pieniądzu, zużycie w konkretnym celu określonych zasobów w przedsiębiorstwie. Według Sawickiego do kosztu można również zaliczyć niektóre wydatki nie będące zużyciem, a związane z prowadzeniem normalnej działalności przedsiębiorstwa [Sawicki 1996, s. 2]. Według Jarugowej natomiast, rachunek kosztów to system objaśniający proces powstawania i transformowania kosztów w podmiotach gospodarczych, który polega na badaniu kosztów i tworzeniu informacji o kosztach i efektach w odniesieniu do danych przyszłych i przeszłych, w celu wspomagania procesów zarządzania podmiotem gospodarczym [Jarugowa 1998, s. 9]. W gospodarce rynkowej każde przedsiębiorstwo ma możliwość stosowania różnorodnych odmian rachunku kosztów, różniących się zasadniczo sposobem i czasem ujęcia informacji, powiązaniami kosztów z ich nośnikami oraz przyjętymi metodami ich kalkulacji.

Czubakowska, Gabrusewicz oraz Nowak definiują rachunek kosztów, jako względnie wyodrębniony podsystem systemu informacyjnego rachunkowości jednostki gospodarczej. Głównym zadaniem rachunku kosztów jest tworzenie (generowanie) informacji dotyczących kosztów działalności przedsiębiorstwa oraz dostosowanie tych informacji do potrzeb użytkowników. W rachunku kosztów dokonuje się zatem transformacja informacji kosztowych w zależności od przyjętego przez przedsiębiorstwo modelu rachunku dotyczącego kosztów. Różnorodne uwarunkowania rynkowe oraz zmienność procesów ponoszenia kosztów i odmienności potrzeb informacyjnych wymuszają na zarządzających powstawanie nowych modeli rachunku kosztów. Autorzy stwierdzają również, iż rachunek kosztów powinien dostarczać użytkownikowi wieloprzekrojowych informacji o kosztach, które to dane mają przyczynić się istotnie do formułowania odpowiednich decyzji w przedsiębiorstwie [Czubakowska, Gabrusewicz, Nowak 2006, s. 106].

W spółdzielniach mleczarskich rachunek kosztów obejmuje dwa układy kosztów: układ rodzajowy oraz według typów działalności. W układzie rodzajowym wyodrębnia się takie składowe rachunku kosztów jak: amortyzacja, zużycie materiałów i energii, zużycie surowca, usługi obce, wynagrodzenia, narzuty na wynagrodzenia (świadczenia na rzecz pracowników), podatki i opłaty oraz pozostałe koszty. Każda ze składowych układu rodzajowego dzieli się dodatkowo na szczegółowe koszty, dostosowane do specyfiki konkretnej spółdzielni np. koszty usług obcych podzielone są dodatkowo na koszty usług transportowych, koszty usług proszkowni itp. w zależności z jakich usług dana spółdzielnia korzysta [Chmielewska 2006, s. 381].

Kalkulacja kosztów w spółdzielniach mleczarskich przeszła i wciąż przechodzi modyfikacje podyktowane urynkowieniem gospodarki, zmianami działalności jednostek gospodarczych, ich struktur i metod zarządzania, wzrostu zapotrzebowania na rzetelne informacje kosztowe oraz rosnącą konkurencją na rynku produktów mleczarskich [Bazydło, Sokołowski 1998, s. 5]. 
Spółdzielnia mleczarska nie ma narzuconych „z góry” schematów kalkulacji. Zarządzający mogą stosować zasady sporządzania kalkulacji produkowanych wyrobów według założeń przyjętych przez zarząd danej spółdzielni lub korzystać z rozwiązań proponowanych przez różnorodne związki i zrzeszenia spółdzielni mleczarskich, z uwzględnieniem norm obowiązujących w rachunkowości. Główną przesłanką sporządzania arkuszy kalkulacyjnych jest ustalenie jednostkowych kosztów poszczególnych wyrobów potrzebnych do podejmowania decyzji cenowych oraz analizy poziomu ponoszonych kosztów na jednostkę produktu.

Artykuły mleczarskie są produktami wytwarzanymi masowo z tego samego surowca, ale w wyniku różnorodnych procesów produkcyjnych, dlatego też spółdzielnie mleczarskie stosują kalkulację podziałową ze współczynnikami oraz doliczeniową. Przy ustalaniu zużycia surowca na jednostkę produkcji stosuje się kalkulację podziałową ze współczynnikami natomiast koszty pośrednie dolicza się do kosztów surowca (mleka) z wykorzystaniem kalkulacji doliczeniowej, za pomocą odpowiednio dobranych kluczy podziałowych [Włodarczyk, Górniak 1992, s. 7].

Na schemacie 1 przedstawiono ujęcie rozliczania kosztów w spółdzielni mleczarskiej.

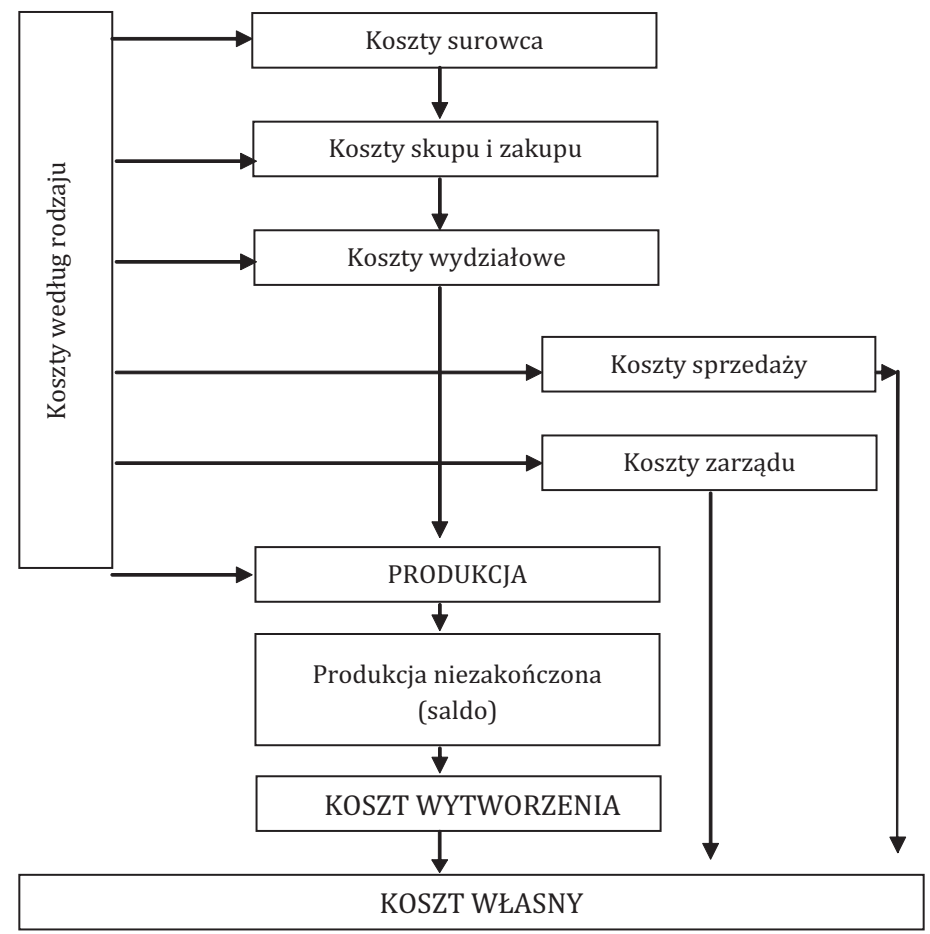

SCHEMAT 1. Rozliczanie kosztów w spółdzielni mleczarskiej

Źródło: opracowanie własne. 


\section{METODY BADAŃ}

Celem badań jest przedstawienie metodyki rozliczania kosztów w spółdzielni mleczarskiej przy wykorzystaniu arkusza rozliczeniowego kosztów. Wybrano w sposób celowy spółdzielnię mleczarską określoną jako obiekt typowy przy wykorzystaniu metody odległości euklidesowej i miejskiej. określenia obiektu typowego z n = 88 spółdzielni mleczarskich określono następujący zestaw zmiennych, które są wspólne dla wszystkich spółdzielni:

- Wartość funduszu własnego (zł)

- Wartość majątku (zł)

- Wartość funduszu udziałowego (zł)

- Wielkość zatrudnienia (os.)

- Wartość przerobionego surowca (zł)

- Poziom kosztów operacyjnych (zł)

- Przeciętny stan należności (zł)

- Przeciętny stan zobowiązań (zł)

- Przychody ze sprzedaży (zł)

- Zysk/strata ze sprzedaży (zł)

- Zysk/strata netto (zł)

- Liczba dostawców (os.)

- Wielkość skupu mleka (hl)

Okres badawczy obejmował 2016 rok. Przy wykorzystaniu metody wywiadu bezpośredniego uzyskano szczegółowe arkusze rozliczeniowe kosztów oraz informacje na temat specyfiki i sposobów rozliczania kosztów w mleczarni.

\section{WYNIKI BADAŃ}

Układ kosztów według typów działalności może być rozpatrywany w różnych przekrojach (klasyfikacjach) dotyczących struktury wewnętrznej kosztów, miejsc ich powstawania (koszty wydziałów pomocniczych, koszty ogólnozakładowe), stopnia powiązania z produkcją (koszty pośrednie i bezpośrednie) oraz według pozycji kalkulacyjnych (surowiec, koszty skupu i zakupu, materiały bezpośrednie, koszty wydziałowe, zarządu oraz koszty sprzedaży). Układ kosztów według typów działalności jest bardziej przydatny dla celów rachunku kosztów w przeciwieństwie do układu rodzajowego, przewidzianego głównie dla potrzeb sprawozdawczych [Wasilewski, Chmielewska 2006, s. 114].

W spółdzielniach mleczarskich poniesione w danym okresie koszty ewidencjonuje się jednocześnie na kontach układu rodzajowego oraz w układzie według typów działalności przy wykorzystaniu tzw. arkusza rozliczeniowego kosztów. Koszty rodzajowe przenosi się zgodnie w miejscem ich powstawania na określone 
konta odpowiadające działalności, w której dany koszt powstał np. koszty zużycia surowca przenosi się w całości na produkcję, ponieważ tylko tam zostały one faktycznie poniesione.

Surowiec mleczny rozlicza się na poszczególne produkty według norm zużycia jednostek tłuszczu i plazmy, uwzględniając niekiedy normę zużycia jednostek białka. Norma zużycia surowca na dany produkt określa ilość jednostek tłuszczowych i jednostek plazmy, jakie wykorzystuje się do wytworzenia jednostki gotowego produktu. Norma zużycia jest różna dla każdego rodzaju produktu (np. dla mleka o zawartości tłuszczu - 2\% wynosi 2,03 jednostki tłuszczu oraz 0,995 jednostki plazmy) i uwzględnia straty poniesione w procesie produkcyjnym. Wartość surowca mlecznego na pojedyncze produkty ujmowana jest w jednostkach tłuszczu i plazmy. Koszt jednostek tłuszczu obliczany jest jako iloczyn ceny jednostki tłuszczu i normy zużycia jednostek tłuszczu na dany wyrób, natomiast wartość jednostek plazmy otrzymuje się przez pomnożenie ceny jednostki plazmy przez normę zużycia tych jednostek na dany wyrób.

Rozliczanie kosztów w spółdzielni mleczarskiej jest procesem specyficznym, gdyż produkcja odbywa się z wykorzystaniem tylko jednego zasadniczego materiału, którym jest skupowane mleko. Materiał (surowiec) ten musi być szybko przetworzony na produkt końcowy, gdyż ma krótki okres przydatności do przerobu, co wymaga odpowiedniej organizacji procesu produkcji. Koszty operacji finansowych związane bezpośrednio z wytwarzaniem produktów rozlicza się przyjmując podstawę naliczania, którą spółdzielnie ustalają we własnym zakresie (najczęściej jest to techniczny koszt wytworzenia, koszty zarządu oraz koszty sprzedaży).

Mając w arkuszu kalkulacyjnym rozliczone wszystkie koszty, ustala się techniczny koszt wytworzenia danego produktu oraz całkowity koszt własny wyrobu. Koszt wytworzenia stanowi sumę zużycia surowca netto, pozostałych materiałów bezpośrednich, kosztów skupu i zakupu oraz kosztów wydziałowych. Całkowity koszt własny ustalany jest jako suma technicznego kosztu wytworzenia danego wyrobu, kosztów ogólnozakładowych oraz kosztów sprzedaży.

Na podstawie kosztu wytworzenia oraz kosztu własnego poszczególnych wyrobów ustala się jednostkowy koszt wytworzenia oraz jednostkowy koszt własny, dzieląc je odpowiednio przez ilość wyprodukowanego rodzaju wyrobu.

Kalkulacja wyrobów mleczarskich obejmuje odrębnie jeszcze dwie pozycje - „wartość produkcji według cen realizacji”, która obejmuje produkcję danego wyrobu pomnożoną przez średnią cenę sprzedaży oraz różnicę między wartością produkcji w cenie realizacji a całkowitym kosztem własnym.

W celu zrealizowania zadań wewnętrznych w systemach rachunku kosztów spółdzielni tworzone są analityczne struktury kosztów według rodzaju. Analityczna struktura kosztów rodzajowych ma na celu urealnienie procesu planowania kosztów i ich kontroli [Sobańska 2009, s. 123]. Rozbudowa układu rodzajowego kosztów, zawierającego siedem rodzajów kosztów, polega na wyodrębnieniu 


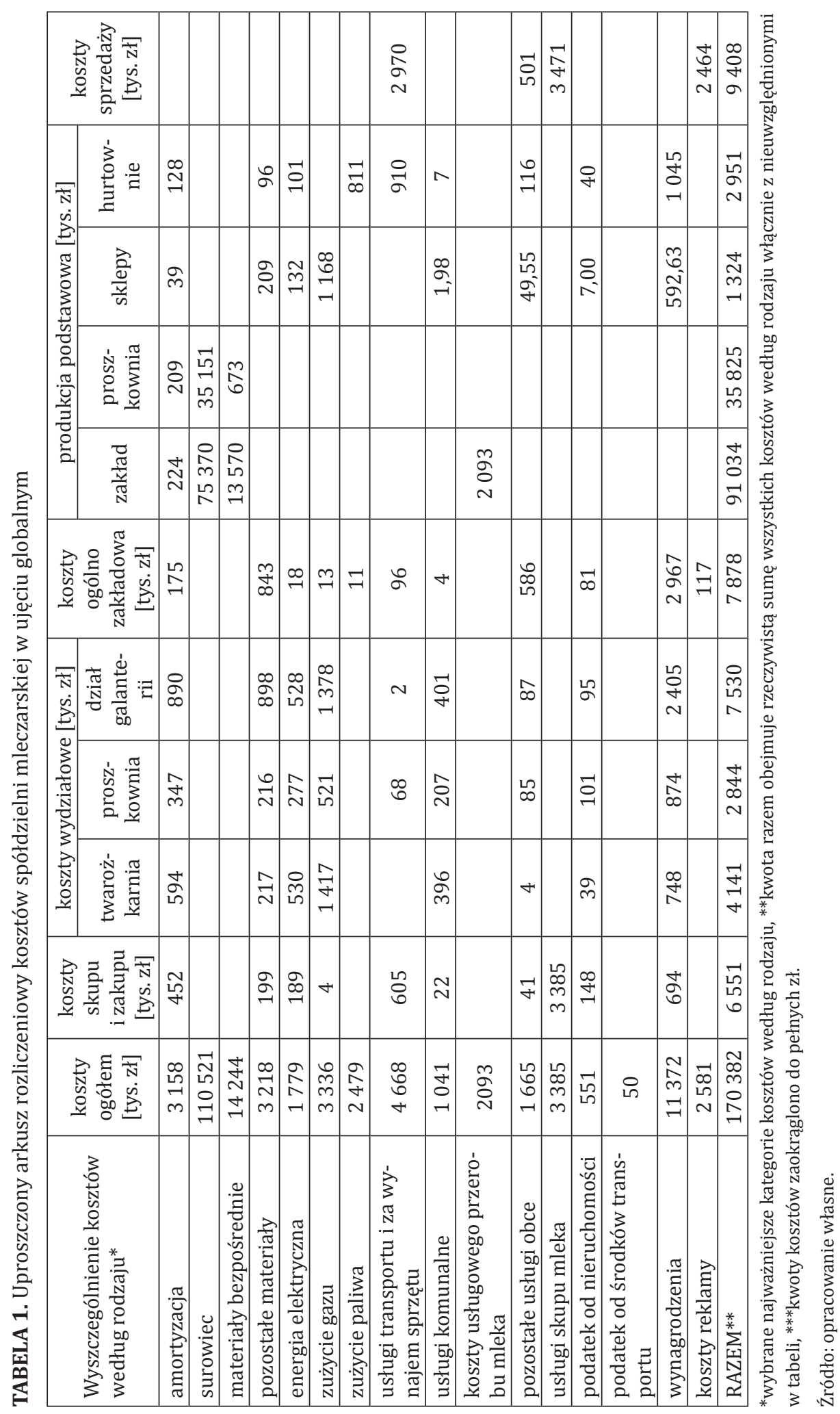


z nich podrodzajów, z podrodzajów natomiast składników kosztów, jeśli jest to podyktowane charakterem i znaczeniem danego podrodzaju oraz potrzebami informacyjnymi kierowników. Zazwyczaj największej dezintegracji w spółdzielni mleczarskiej podlegają następujące rodzaje kosztów: zużycie materiałów i energii, usługi obce oraz wynagrodzenia

Najwyższe koszty według rodzaju w badanej spółdzielni to surowiec mleczny (110 521 tys. zł), który jest generowany głównie w zakładzie produkcyjnym (75 370 tys. zł) oraz proszkowni mleka 935151 tys. zł). Drugimi co do wartości kosztami są materiały bezpośrednie oraz wynagrodzenia (odpowiednio 14244 tys. zł i 11372 tys. zł). Może to oznaczać, iż wyniki finansowe spółdzielni są najbardziej wrażliwe na zmiany cen surowca mlecznego, cen materiałów bezpośrednich oraz zatrudnienia. Na uwagę zasługuje fakt, iż koszt surowca (dostarczany przez rolników dostawców - członków spółdzielni) im wyższy, tym bardziej spółdzielnia maksymalizuje korzyści swoich członków poprzez wyższą cenę za dostarczany surowiec. Zarządzający spółdzielnią muszą jednak pogodzić dwa sprzeczne cele - ten wynikający ze statutu oraz umożliwiający rozwój przedsiębiorstwa wyrażający się w uzyskiwaniu wyników finansowych.

W celu uzupełnienia analiz dotyczących rozliczania kosztów z wykorzystaniem arkusza rozliczeniowego kosztów zapytano zarządzających badana spółdzielnią o zakres zarządzania kosztami na podstawie tego narzędzia (tabela 2).

Arkusz rozliczeniowy kosztów w badanej spółdzielni służy głównie do celów sprawozdawczych oraz kontroli kosztów jednocześnie w układzie rodzajowym i kalkulacyjnym. Rozbudowana postać arkusza oraz szczegółowe ujęcie kosztów według rodzaju pozwala uzyskać informacje o ich poziomie oraz miejscu powstania, co umożliwia wychwycenie wzrostu kosztów i ustalenie przyczyny.

TABELA 2. Wykorzystanie informacji z arkusza rozliczeniowego kosztów w opinii zarządzających badaną spółdzielnią

\begin{tabular}{|c|c|c|}
\hline \multirow{2}{*}{ Treść } & \multicolumn{2}{|c|}{$\begin{array}{l}\text { Opinie zarządzających } \\
\text { spółdzielnią (wskazania) }\end{array}$} \\
\hline & $\begin{array}{l}\text { księgowość } \\
\text { (3 osoby) }\end{array}$ & $\begin{array}{c}\text { zarząd } \\
\text { (2 osoby) }\end{array}$ \\
\hline \multicolumn{3}{|c|}{$\begin{array}{l}\text { Informacje z arkusza rozliczeniowego kosztów } \\
\text { zaspokajają potrzeby decyzyjne w zakresie*: }\end{array}$} \\
\hline a) informacji o kosztach według rodzaju, & 1 & 0 \\
\hline b) całkowitych kosztów w miejscach ich powstawania, & 1 & 0 \\
\hline c) sprawozdawczym & 3 & 2 \\
\hline $\begin{array}{l}\text { d) kontroli kosztów zarówno w układzie kalkulacyjnym, } \\
\text { jak i rodzajowym }\end{array}$ & 3 & 2 \\
\hline
\end{tabular}

*zaznaczona co najmniej jedna odpowiedź.

Źródło: opracowanie własne. 


\section{WNIOSKI}

Rachunek kosztów to wszelkie czynności, których celem jest ustalenie i interpretacja poniesionych nakładów na wytworzoną produkcję w danym czasie. Koszty powinny być rozliczane i badane $\mathrm{w}$ miejscach ich powstawania lub $\mathrm{w}$ powiązaniu z działaniami, które powodują ich występowanie. Każdy rachunek kosztów powinien być poprzedzony analizą wewnątrzzakładowych powiązań między produkcją a kosztami, ewidencją kosztów według miejsc ich powstawania oraz znajomością zależności między nośnikami kosztów a samymi kosztami.

Arkusz rozliczeniowy kosztów stosowany w spółdzielniach mleczarskich może stanowić dobre narzędzie do analizy oraz kontroli kosztów. Sporządzany w krótszych okresach czasu np. miesięcznie, czy raz na kwartał umożliwia ocenę poziomu, rodzaju oraz miejsc powstawania kosztów. Ewidencja kosztów działalności mleczarni zależy przede wszystkim od potrzeb informacyjnych kierownictwa jednostki. Spółdzielnie mleczarskie prowadzące jednorodną działalność gospodarczą (np. tylko produkcja serów) prowadzą zazwyczaj ewidencję kosztów wyłącznie w układzie rodzajowym, ponieważ nie istnieje tu konieczność rozliczania kosztów według miejsc powstawania oraz wytwarzanych produktów, co jest niezbędne w mleczarniach, których działalność ma charakter wielobranżowy czy wytwórczy - czyli w większości polskich spółdzielni w sektorze mleczarskim.

Spółdzielnie mleczarskie mogą ewidencjonować koszty w trzech układach, czyli stosować tzw. pełną ewidencję kosztów. Pełna ewidencja kosztów obejmuje grupowanie kosztów prostych w układzie rodzajowym, ich rozliczenie według miejsc powstawania oraz kalkulację jednostkowego kosztu wytworzenia. Dotychczas spółdzielnie mleczarskie wykorzystują do zarządzania informacje pochodzące głównie z rachunku kosztów pełnych oraz arkusza rozliczeniowego kosztów.

\section{Spis literatury}

BAZYDŁO I., Sokołowski T. 1998: Rozliczanie surowca w zakładach mleczarskich. Krajowe Porozumienie Spółdzielni Mleczarskich, Związek Rewizyjny, Warszawa.

CHMIELEWSKA M. 2006: Kalkulacja kosztów spółdzielni mleczarskiej z wykorzystaniem różnych podstaw podziału kosztów pośrednich. Zarządzanie produkcją i logistyką - koncepcje, metody i rozwiązania praktyczne. Wydawnictwo Instytutu Inżynierii Zarządzania Politechniki Poznańskiej, Poznań.

CZUBAKOWSKA K., GABRUSEWICZ W., NOWAK E. 2006: Podstawy rachunkowości zarządczej. Wydawnictwo PWE, Warszawa.

DERBECK VAN E.J. 2014: Principles of Cost Accounting, South-Western Gengage Learning, Mason.

GABRUSEWICZ W., KAMELA-SOWIŃSKA A. POETSCHKE H. 1998: Rachunkowość zarządcza. Wydawnictwo PWE, Warszawa. 
JARUGA A., NOWAK W., SZYCHTA A. 1999: Rachunkowość zarządcza - koncepcje i zastosowania. Wydawnictwo Absolwent, Łódź.

JARUGA A., KABALSKI P., SZYCHTA A. 2010: Rachunkowość zarządcza, Wolters Kluwer, Warszawa.

JARUGOWA A. (red.) 1998: Rachunek kosztów i rachunkowość zarządcza. Wydawnictwo SKwP, Warszawa.

MORSE W.J., DAVIES J.R., HARTGRAVES A.L., 2013: Management Accounting. A Strategic Approach, South-Western Thomson Learning, London.

NOWAK E., 2010: Problemy rozwoju strategicznej rachunkowości zarządczej, Zeszyty Teoretyczne Rachunkowości, t. 56, z.112, s. 161-173.

ROGOWSKA E. 2013: Systematyczny rachunek kosztów jako narzędzie wspomagające pozyskiwanie informacji do celów zarządzania przedsiębiorstwem, Zeszyty Naukowe Uniwersytetu Szczecińskiego nr 765, „Finanse, Rynki Finansowe, Ubezpieczenia” nr 61 , t. 2, s. 225-341.

SAWICKI K. (red.) 1996: Rachunek kosztów. Fundacja Rozwoju Rachunkowości w Polsce, Warszawa.

SOBAŃSKA I. 2009: Podstawy rachunku kosztów i wyników, w: Rachunek kosztów. Podejście operacyjne i strategiczne, red. I. Sobańska, Wydawnictwo C.H. Beck, Warszawa.

WASILEWSKI M., CHMIELEWSKA M. 2006: Praktyczne aspekty budżetowania kosztów w spółdzielniach mleczarskich. Prace Naukowe Akademii Ekonomicznej we Wrocławiu, Controlling w małych i średnich przedsiębiorstwach, Nr 1125, s. 123-137.

WŁODARCZYK H., GÓRNIAK J. 1992: Wzorcowy rachunek kosztów dla spółdzielni mleczarskich. Wydawnictwo Sanpollac sp. z o.o., Warszawa.

\title{
THE USEFULNESS OF COSTS WORKSHEET TO MANAGE COSTS IN DAIRY COOPERATIVES
}

\begin{abstract}
The aim of the research is to provide an accounting scheme in dairy cooperatives and to determine its usefulness in obtaining cost information for management decision making. Analysis of the nature of the case study. Intentionally selected dairy cooperative referred to as a typical using Euclidean distance method. Managers need reliable cost information. Providing this information is the main task of the cost account, which is one of the most important components of the accounting, with the task group and setting a number of dependencies between processes, and the amount of the costs. Properly drawn up the billing sheet costs should take into account changes in both production and market environment, the dairy cooperative, because these factors justify a demand for information about the cost.
\end{abstract}

Key word: worksheet of costs, dairy cooperatives, cost accounting. 